\title{
PENERAPAN PEMBAGIAN KOMPILASI HUKUM ISLAM (KHI) PASAL 177 DAN PASAL 178 TENTANG BAGIAN ORANG TUA
}

\author{
Syuhada' \\ Institut Agama Islam Bani Fattah Jombang Indonesia \\ syuhada@,iaibafa.ac.id
}

\begin{abstract}
Abstrak: Bagian-bagian pasti yang ditentukan oleh Allah swt. dalam kitab suci al-qur'an adalah : $1 / 2,1 / 4,1 / 8$ dan $2 / 3$, $1 / 3,1 / 6$, bagian pasti tersebut adalah dari harta peninggalan (HP), kecuali dalam kasus al-gharrawain, yaitu ibu mendapat bagian $1 / 3$ sisa, yaitu bagian $1 / 3$ setelah dikurangi bagian suami atau bagian istri.

Dalam Alqur'an surat An-nisa' ayat 11, Ibu apabila mewaris bersama bapak dan mayat tidak meninggalkan anak dan cucu (walad) maka ibu mendapat bagian $1 / 3$ dan bapak mendapatkan sisanya (2/3), itu artinya ibu mendapatkan satu bagian sedangkan bapak mendapatkan dua bagian. Jadi ayat tersebut menciptakan asas "jika terdapat ahli waris yang sama tetapi beda jenis, maka bagian perempuan separuh dari bagian laki-laki" asas tersebut berlaku bagi orang tua (Ibu dan Bapak) satu bagian diberikan kepada ibu sebab perempuan dan dua bagian diberikan bapak sebab laki-laki.
\end{abstract}

Oleh sebab itu dalam kasus Al-Gharrawain, ibu mendapatkan $1 / 3$ sisa (satu bagian) yaitu sepertiganya setelah diambil bagian suami atau bagian istri, sedangkan bagian bapak menjadi $2 / 3$ (dua bagian). Istilah yang digunakan oleh para shababat untuk bagian yang diterima oleh ibu adalah Tsulutsul 
Bâqi, yaitu sepertiga sisa, sebab berbuat sopan santun dengan surat An-nisa' ayat 11.

Kata Kunci: KHI, bagian waris orang tua, pasal 177 KHI.

\section{Pendahuluan}

Kompilasi Hukum Islam (KHI) pasal 176 adalah "Ayah mendapat sepertiga bagian bila pewaris tidak meningalkan anak, bila ada anak, ayah mendapat seperenam bagian" Ayah mendapat sepertiga bagian ini salah yang benar adalah "Ayah mendapat seperenam bagian bila pewaris meninggalkan anak laki-laki dan mendapat seperenam dan sisa bila pewaris meninggalkan anak perempuan, bila tidak ada anak, ayah mendapat seluruh harta peninggalan“

Kompilasi Hukum Islam (KHI) pasal 178 adalah:

1) "Ibu mendapat seperenam bagian bila bila ada anak atau dua saudarah atau lebih. Bila tidak ada anak atau dua orang saudara atau lebih, maka ia mendapat sepertiga bagian"

2) "Ibu mendapat sepertiga bagian dari sisa sesudah diambil oleh janda atau duda bila bersama-sama dengan ayah", ini dikenal dengan kasus Grawain.

Sebagimana penjelasan Alqur'an surat An-nisa' ayat 11 Bagian orang tua (Bapak-Ibu).
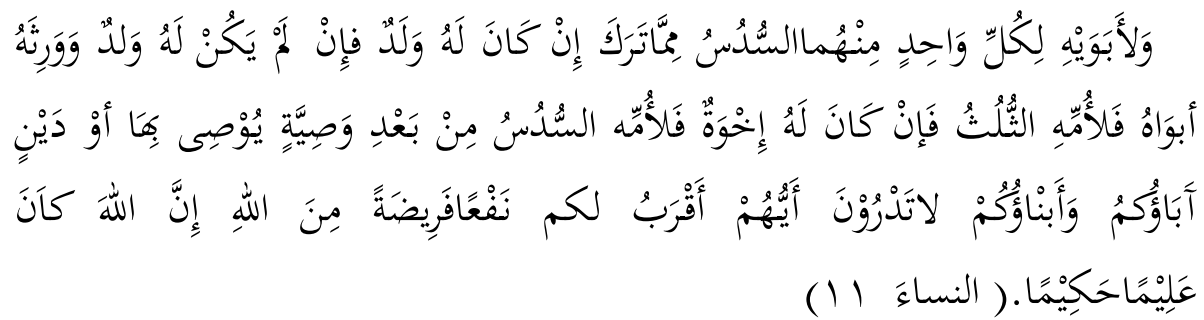

Dan untuk dua orang ibu bapak, bagi masing-masing seperenam dari harta yang ditinggalkan, jika yang meninggal itu mempunyai anak, jika orang yang meninggal tidak mempunyai anak dan ia diwarisi oleh ibu-bapaknya (saja), maka ibunya mendapat sepertiga, jika yang meninggal itu mempunyai beberapa saudara, maka ibunya mendapat seperenam, (pembagian-pembagian tersebut di atas) sesudah dipenuhi wasiat yang ia buat atau (dan) sesudah dibayar hutangnya. (Tentang) orang tuamu dan anak-anakmu, kamu 
tidak mengetahui siapa di antara mereka yang lebih dekat (banyak) manfa'atnya bagimu. Ini adalah ketetapan dari Allah. Sesungguhnya Allah Maha Mengetahui lagi Maha Bijaksana. (Q.S. An-Nisâ': 11). ${ }^{1}$

\section{PENJELASAN}

\section{Bapak Dan Bagiannya}

Bapak adalah seorang laki-laki yang berstatus sebagai suami ibunya mayat di waktu mayat berada dalam kandungan ( $\mathrm{rah}$ im $)$.

Bagian bapak atas harta peninggalan putra putrinya adalah :

\begin{tabular}{|c|c|c|c|}
\hline \multicolumn{3}{|c|}{ Bagian Bapak } & Penjelasan \\
\hline 1 & آلسشُدُسُ & $1 / 6$ & $\begin{array}{l}\text { Jika mayat meninggalkan anak atau } \\
\text { cucu laki-laki (walad) }\end{array}$ \\
\hline 2 & اكسُّدُسُ وَالبَاقِيْ & $\begin{array}{l}1 / 6 \\
+S\end{array}$ & $\begin{array}{l}\text { Jika mayat meninggalkan anak atau } \\
\text { cucu perempuan (walad) }\end{array}$ \\
\hline 3 & تَصَبَةُ بِالنَّفْسِ & S & $\begin{array}{l}\text { Jika mayat tidak meninggalkan anak } \\
\text { atau cucu (walad) }\end{array}$ \\
\hline
\end{tabular}

Contoh: Bagian bapak $1 / 6$

\begin{tabular}{|c|c|c|c|}
\hline \multicolumn{2}{|c|}{ Ahli waris } & \multicolumn{2}{|c|}{ Asal Masalah : 12} \\
\hline 1 & زَوْجْج & $1 / 4$ & 3 bagian \\
\hline 2 & أَبٌْ & $1 / 6$ & 2 bagian \\
\hline 3 & إبْنْ & Sisa & 7 bagian \\
\hline
\end{tabular}

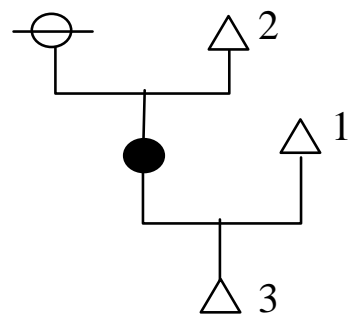

\section{Penjelasan :}

1. Suami mendapat bagian $1 / 4$ sebab mayat meninggalkan anak.

2. Bapak mendapat $1 / 6$ sebab mayat meninggalkan anak laki-laki.

3. Anak laki-laki mendapat sisa sebab 'ashabah binnafs.

Misalkan harta peninggalan Rp 24.000.000, maka pembagiannya adalah : $\frac{H P: R p 24.000 .000}{A M: 12}=R p 2.000 .000$

\begin{tabular}{|c|c|c|c|c|}
\hline \multicolumn{2}{|c|}{ Ahli waris } & \multicolumn{3}{|c|}{ Bagian masing-masing Ahli Waris : } \\
\hline 1 & زَوْْجْ & 3 bagian x Rp 2.000 .000 & $\mathrm{Rp}$ & 6.000 .000 \\
\hline
\end{tabular}

1 Departemen agama, Al-Qur'an, 117. 


\begin{tabular}{|c|c|c|c|}
\hline 2 & أَبُْ & 2 bagian x Rp 2.000 .000 & Rp $\quad 4.000 .000$ \\
\hline 3 & إِبْتُ & 7 bagian x Rp 2.000 .000 & Rp 14.000 .000 \\
\hline \multicolumn{3}{|r|}{ Jumlah } & Rp 24.000 .000 \\
\hline
\end{tabular}

Contoh: Bapak mendapat $1 / 6+$ sisa

\begin{tabular}{|c|c|c|c|c|}
\hline \multicolumn{2}{|c|}{ Ahli waris } & \multicolumn{3}{|c|}{ Asal Masalah : 12} \\
\hline 1 & زَوْْجُ & $1 / 4$ & 3 & 3 bagian \\
\hline 2 & أَبُجُ & $1 / 6+S$ & $2+1$ & 3 bagian \\
\hline 3 & بِنْتُ & $1 / 2$ & 6 & 6 bagian \\
\hline
\end{tabular}

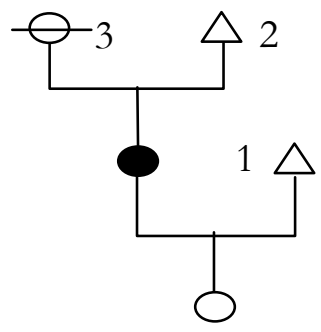

\section{Penjelasan :}

1. Suami mendapat $1 / 4$ sebab ada anak.

2. Bapak mendapat $1 / 6$ dan sisa, sebab ada anak perempuan.

3. Anak perempuan mendapat bagian $1 / 2$, sebab seorang.

Misalkan harta peninggalan Rp 24.000.000, maka pembagiannya adalah: $\frac{H P: R p 24.000 .000}{A M: 12}=R p 2.000 .000$

$A M: 12$

\begin{tabular}{|c|c|c|c|}
\hline \multicolumn{2}{|c|}{ Ahli waris } & \multicolumn{2}{|c|}{ Bagian masing-masing Ahli Waris : } \\
\hline 1 & زَزوْجْْ & 3 bagian x Rp 2.000 .000 & Rp $\quad 6.000 .000$ \\
\hline 2 & أَبُْ & 3 bagian x Rp 2.000 .000 & Rp $\quad 6.000 .000$ \\
\hline 3 & بِنْتِ & 6 bagian x Rp 2.000 .000 & Rp 12.000 .000 \\
\hline & & Jumlah & Rp 24.000 .000 \\
\hline
\end{tabular}

Contoh: Bapak mendapat bagian sisa

\begin{tabular}{|c|c|c|c|}
\hline \multicolumn{2}{|c|}{ Ahli waris } & \multicolumn{2}{|c|}{$\mathrm{AM}: 2$} \\
\hline 1 & زَوْْْجْ & $1 / 2$ & 1 bagian \\
\hline 2 & أََبُْ & Sisa & 1 bagian \\
\hline 3 & أَ خُحْ شَقِيْقٌِ & Mabjûb & - \\
\hline
\end{tabular}

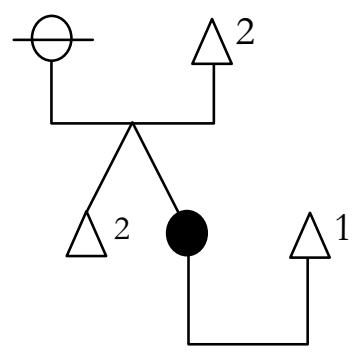




\section{Penjelasan :}

1. Suami mendapat $1 / 2$ sebab tidak ada anak dan cucu.

2. Bapak mendapat sisa sebab tidak ada anak dan cucu.

3. Saudara laki-laki sekandung dihalangi oleh bapak. Sebab bapak urutan kelompok kedua dalam 'ashabah binnafs sedangkan saudara laki-laki sekandung urutan ketiga.

Contoh: Bapak mendapat $1 / 6+$ sisa

\begin{tabular}{|c|c|c|c|c|}
\hline \multicolumn{2}{|c|}{ Ahli waris } & \multicolumn{3}{|c|}{ Asal Masalah : 24} \\
\hline 1 & زَوْجَةٌُ & $1 / 8$ & 3 & 3 bagian \\
\hline 2 & أَبَُْ & $1 / 6+S$ & $4+3$ & 9 bagian \\
\hline 3 & بِنْتُ ابْنِ & $1 / 2$ & 12 & 12 bagian \\
\hline
\end{tabular}

\section{Penjelasan :}

1. Istri mendapat $1 / 8$ sebab ada anak.

2. Bapak mendapat $1 / 6$ dan sisa, sebab ada cucu perempuan.

3. Cucu perempuan mendapat bagian $1 / 2$, sebab seorang.

Misalkan harta peninggalan Rp 24.000.000, maka pembagiannya adalah : $\frac{H P: R p 24.000 .000}{A M: 24}=R p 1.000 .000$

\begin{tabular}{|c|c|c|c|}
\hline \multicolumn{2}{|c|}{ Ahli waris } & \multicolumn{2}{|c|}{ Bagian masing-masing Ahli Waris : } \\
\hline 1 & 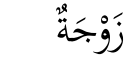 & 3 bagian x Rp 1.000 .000 & Rp $\quad 3.000 .000$ \\
\hline 2 & أُبُْ & 9 bagian x Rp 1.000 .000 & Rp $\quad 9.000 .000$ \\
\hline 3 & بِنْتُ ابْنِ & 12 bagian x Rp 1.000 .000 & Rp 12.000 .000 \\
\hline & & Jumlah & $\mathrm{Rp} \quad 24.000 .000$ \\
\hline
\end{tabular}

Contoh: Bapak mendapat bagian sisa

\begin{tabular}{|c|c|c|c|}
\hline \multicolumn{2}{|c|}{ Ahli waris } & \multicolumn{2}{|c|}{$\mathrm{AM}: 4$} \\
\hline 1 & زَوْْجةٌُ & $1 / 4$ & 1 bagian \\
\hline 2 & أََبِْ & Sisa & 3 bagian \\
\hline 3 & أَ خُخ شَقَقِيقُقُ & Mabjūb & - \\
\hline
\end{tabular}




\section{Penjelasan :}

1. Istri mendapat $1 / 4$ sebab tidak ada anak dan cucu.

2. Bapak mendapat sisa sebab tidak ada anak dan cucu.

3. Saudara laki-laki sekandung dihalangi oleh bapak. Sebab bapak urutan kelompok kedua dalam 'ashabah binnafs sedangkan saudara laki-laki sekandung urutan ketiga.

Misalkan harta peninggalan Rp 24.000.000, maka pembagiannya adalah : $\frac{H P: R p 24.000 .000}{A M: 2}=R p 12.000 .000$

\begin{tabular}{|c|c|c|c|}
\hline \multicolumn{2}{|c|}{ Ahli waris } & \multicolumn{2}{|c|}{ Bagian masing-masing } \\
\hline 1 & زَوْْجَةُ & 1 bagian $\mathrm{x}$ Rp 12.000 .000 & $\mathrm{Rp} 12.000 .000$ \\
\hline 2 & أََبُْ & 1 bagian $\mathrm{x}$ R 12.000 .000 & $\mathrm{Rp} 12.000 .000$ \\
\hline 3 & أَ خُ شَقِيْقُ & 0 bagian x Rp 12.000 .000 & $\mathrm{Rp} 0$ \\
\hline \multicolumn{3}{|r|}{ Jumlah } & Rp 24.000 .000 \\
\hline
\end{tabular}

Contoh: Bapak mendapat bagian sisa

\begin{tabular}{|c|c|c|c|}
\hline \multicolumn{2}{|c|}{ Ahli waris } & \multicolumn{2}{|c|}{$\mathrm{AM}: 8$} \\
\hline 1 & زَوْجَحةُ & $1 / 8$ & 1 bagian \\
\hline 2 & أَبُْ & Sisa & 7 bagian \\
\hline 3 & أََُْْ لِأَبْ & Mabjûb & - \\
\hline
\end{tabular}

\section{Penjelasan :}

1. Istri mendapat $1 / 4$ sebab tidak ada anak dan cucu.

2. Bapak mendapat sisa sebab tidak ada anak dan cucu.

3. Saudara laki-laki sebapak dihalangi oleh bapak. Sebab bapak urutan kelompok kedua dalam 'ashabah binnafs sedangkan saudara laki-laki sekandung urutan ketiga.

Misalkan harta peninggalan Rp 24.000.000, maka pembagiannya adalah : $\frac{H P: R p 24.000 .000}{A M: 4}=R p 6.000 .000$ 


\begin{tabular}{|c|c|c|c|}
\hline \multicolumn{2}{|c|}{ Ahli waris } & \multicolumn{2}{|c|}{ Bagian masing-masing } \\
\hline 1 & 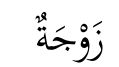 & 1 bagian $x$ Rp 3.000 .000 & Rp 3.000 .000 \\
\hline 2 & أَبٌْ & 7 bagian $x$ Rp 3.000 .000 & Rp 21.000 .000 \\
\hline 3 & أََ خْْ لِأَبِ & 0 bagian x Rp 3.000 .000 & Rp 0 \\
\hline & & Jumlah & $\mathrm{Rp} \quad 24.000 .000$ \\
\hline
\end{tabular}

\section{Ibu Dan Bagiannya}

Ibu adalah seorang perempuan yang melahirkan mayat. Ibu tersebut masih hidup pada waktu mayat meninggal.

Bagian-bagian ibu atas harta peninggalan putra putrinya adalah :

\begin{tabular}{|c|c|c|c|}
\hline \multicolumn{3}{|c|}{ Bagian Ibu } & Penjelasan \\
\hline 1 & الثَُُُُّْ & $1 / 3$ & $\begin{array}{l}\text { Apabila mayat tidak meninggalkan } \\
\text { anak, cucu, dan dua sdr atau lebih }\end{array}$ \\
\hline 2 & آلسُُّدُسُ & $1 / 6$ & $\begin{array}{l}\text { Apabila mayat meninggalkan anak, } \\
\text { cucu, atau dua sdr atau lebih }\end{array}$ \\
\hline 3 & تُلُثُ البَاقِى & $1 / 3 \mathrm{~S}$ & $\begin{array}{l}\text { Apabila mayyit meninggalkan bapak dan } \\
\text { salah satu suami istri. khusus dalam kasus } \\
\text { Gharrâwain }\end{array}$ \\
\hline
\end{tabular}

\section{Penjelasan Bagian Ibu}

Saudara di sini yang dimaksud adalah :

1. Saudara sekandung laki-laki maupun perempuan;

2. Saudara seayah laki-laki maupun perempuan;

3. Saudara seibu laki-laki maupun perempuan.

Mereka mendapat warisan maupun tidak (mahjub)

Contoh: Bagian Ibu 1/3

\begin{tabular}{|c|c|c|c|}
\hline \multicolumn{2}{|c|}{ Ahli waris } & \multicolumn{2}{|c|}{$A M: 6$} \\
\hline 1 & زَوْجْجُ & $1 / 2$ & 3 bagian \\
\hline 2 & أُ & $1 / 3$ & 2 bagian \\
\hline 3 & أَ خُخ شَقَقِيقٌُ & Sisa & 1 bagian \\
\hline
\end{tabular}

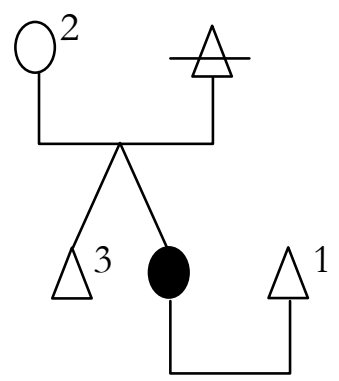




\section{Penjelasan :}

1. Suami mendapat bagian $1 / 2$ sebab tidak ada anak dan cucu.

2. Ibu mendapat bagian $1 / 3$, sebab tidak ada anak dan dua saudara.

3. Saudara laki-laki sekandung mendapat bagian sisa.

\section{CATATAN :}

Jika mayat tidak mempunyai bapak, ibu tetap dapat mewaris dari anaknya dan dari keturunan anaknya.

Contoh, bagian ibu $1 / 6$

\begin{tabular}{|c|c|c|c|}
\hline \multicolumn{2}{|c|}{ Ahli waris } & \multicolumn{2}{|c|}{$\mathrm{AM}: 12$} \\
\hline 1 & زَوْجْج & $1 / 4$ & 3 bagian \\
\hline 2 & 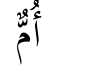 & $1 / 6$ & 2 bagian \\
\hline 3 & إبْنُ & Sisa & 7 bagian \\
\hline
\end{tabular}

\section{Penjelasan :}

1. Suami mendapat bagian $1 / 4$ sebab ada anak.

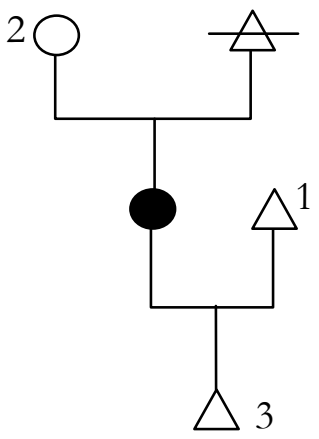

2. Ibu mendapat bagian $1 / 6$, sebab ada anak.

3. Anak laki-laki mendapat bagian sisa.

Misalkan harta peninggalan Rp 24.000.000, maka pembagiannya adalah : $\frac{H P: R p 24.000 .000}{A M: 12}=R p 2.000 .000$

\begin{tabular}{|c|c|c|c|}
\hline \multicolumn{2}{|c|}{ Ahli waris } & \multicolumn{2}{|c|}{ Bagian masing-masing } \\
\hline 1 & زَوَجْجُ & 3 bagian x Rp 2.000 .000 & Rp $\quad 6.000 .000$ \\
\hline 2 & 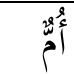 & 2 bagian x Rp 2.000 .000 & Rp $\quad 4.000 .000$ \\
\hline 3 & إبْنْ & 7 bagian x Rp 2.000 .000 & Rp $\quad 14.000 .000$ \\
\hline \multicolumn{3}{|r|}{ Jumlah } & Rp 24.000 .000 \\
\hline
\end{tabular}

Contoh, bagian ibu $1 / 6$

\begin{tabular}{|c|c|c|c|}
\hline \multicolumn{2}{|c|}{ Ahli waris } & \multicolumn{2}{|c|}{$\mathrm{AM}: 24$} \\
\hline 1 & زَوْجَةُّ & $1 / 8$ & 3 bagian \\
\hline 2 & 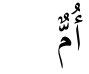 & $1 / 6$ & 4 bagian \\
\hline
\end{tabular}




\begin{tabular}{|l|l|l|l|}
\hline 3 & إبْنُ & Sisa & 17 bagian \\
\hline
\end{tabular}

\section{Penjelasan :}

1. Istri mendapat bagian $1 / 8$ sebab ada anak.

2. Ibu mendapat bagian $1 / 6$ sebab ada anak.

3. Anak laki-laki mendapat bagian sisa.

Misalkan harta peninggalan Rp 24.000.000, maka pembagiannya adalah : $\frac{H P: R p 24.000 .000}{A M: 24}=R p 1.000 .000$

\begin{tabular}{|c|c|c|c|}
\hline \multicolumn{2}{|c|}{ Ahli waris } & \multicolumn{2}{|c|}{ Bagian masing-masing } \\
\hline 1 & زَوَْْجَةٌ & 3 bagian x Rp 1.000 .000 & Rp $\quad 3.000 .000$ \\
\hline 2 & أَمٌْ & 4 bagian x Rp 1.000 .000 & $\mathrm{Rp} \quad 4.000 .000$ \\
\hline 3 & الِبْنْ & 17 bagian $x$ Rp 1.000 .000 & Rp 17.000 .000 \\
\hline & & Jumlah & $\mathrm{Rp} \quad 24.000 .000$ \\
\hline
\end{tabular}

Contoh, bagian ibu $1 / 6$

\begin{tabular}{|c|c|c|c|}
\hline \multicolumn{2}{|c|}{ Ahli waris } & \multicolumn{2}{|c|}{$\mathrm{AM}: 12$} \\
\hline 1 & زَوْْجْ & $1 / 4$ & 3 bagian \\
\hline 2 & | & $1 / 6$ & 2 bagian \\
\hline 3 & إِنْنُ ابْنِ & Sisa & 7 bagian \\
\hline
\end{tabular}

\section{Penjelasan :}

1. Suami mendapat bagian $1 / 4$ sebab ada anak.

2. Ibu mendapat bagian $1 / 6$ sebab ada anak.

3. Cucu laki-laki mendapat bagian sisa.

Misalkan harta peninggalan Rp 24.000.000, maka pembagiannya adalah : $\frac{H P: R p 24.000 .000}{A M: 12}=R p 2.000 .000$ 


\begin{tabular}{|c|c|c|c|}
\hline \multicolumn{2}{|c|}{ Ahli waris } & \multicolumn{2}{|c|}{ Bagian masing-masing } \\
\hline 1 & 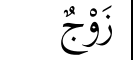 & 3 bagian x Rp 2.000 .000 & $\mathrm{Rp} \quad 6.000 .000$ \\
\hline 2 & أحُ & 2 bagian $x$ Rp 2.000 .000 & $\mathrm{Rp} \quad 4.000 .000$ \\
\hline 3 & إبنُْ ابْنِ & 7 bagian x Rp 2.000 .000 & Rp $\quad 14.000 .000$ \\
\hline \multicolumn{3}{|r|}{ Jumlah } & Rp 24.000 .000 \\
\hline
\end{tabular}

\section{GHARRÂWAIN DAN MUSYTARAKAH}

\section{Al-Gharrâwain (الَغَّرَوَينِ)}

\section{Pengertian}

Al-Gharrâwain bermakna dua bintang yang cemerlang/terkenal. Kasus al-gharrâwain belum pernah terjadi dan diputuskan oleh Rasulullah saw. Dalam kasus al-gharrâwain bagian ibu sepertiga sisa, yaitu sepertiga setelah diambil bagian suami atau istri. Bagian sepertiga sisa tidak disebutkan secara langsung baik dalam Al-Qur'an maupun hadist. Keputusan Sahabat 'Umar bin Khaththâb r.a. dalam kasus ini sangat terkenal dalam kajian ilmu farầidh. Oleh karena itu dinamakan algharrâwain.

Kasus tersebut juga dinamakan 'Umariyyatain berkenaan dengan keputusan Sahabat 'Umar bin Khaththâb r.a. Ibu mendapat sepertiga sisa terdapat dua kasus yang terkenal dengan nama 'Umariyatain. ${ }^{2}$

\section{Macam-Macam Kasus Gharrawain}

Ibu mendapat bagian $1 / 3$ sisa dalam terdapat dua kasus, yaitu :

1) Seorang perempuan meninggal, ahli waris : suami, ibu, dan bapak.

Penyelesaiannya adalah sebagai berikut:

\begin{tabular}{|c|c|c|c|c|}
\hline \multicolumn{2}{|c|}{ Ahli waris } & \multicolumn{3}{|c|}{$\mathrm{AM}: 6$} \\
\hline 1 & زَوْْجْ & $1 / 2$ & 3 & 3 bagian \\
\hline 2 & |ُ أُ & $1 / 3$ sisa & 3 & 1 bagian \\
\hline
\end{tabular}

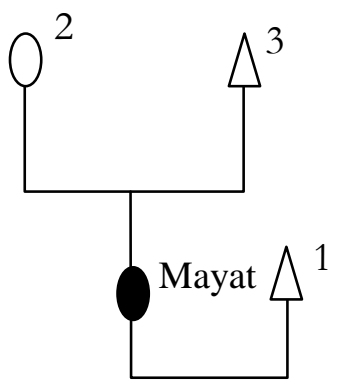

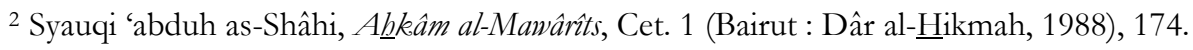
10 Syuhada' - Penerapan Pembagian KHI 


\begin{tabular}{|l|l|l|l|l|}
\hline 3 & $\operatorname{li}^{3}$ & Sisa & & 2 bagian \\
\hline
\end{tabular}

\section{Penjelasan :}

1. Bilangan 6 menjadi Asal Masalah. Perbandingan mubâyanah.

2. Suami mendapat 3 bagian kemudian sisanya 3 bagian diberikan pada ibu 1 bagian $=1 /{ }_{3}$ sisa dan bapak 2 bagian $={ }^{2 / 3}$ sisa.

3. Penyelesaian di atas menjadikan bagian ibu separuh dari bagian yang diterima oleh bapak.

$$
\text { HP Rp 12.000.000, maka : } \frac{H P . R p 12.000 .000}{A M: 6}=R p 2.000 .000
$$

\begin{tabular}{|c|c|c|c|}
\hline \multicolumn{2}{|c|}{ Ahli waris } & \multicolumn{2}{|c|}{ Bagian yang diterima } \\
\hline 1 & زَوْْجْ & 3 bagian x Rp 2.000 .000 & Rp $\quad 6.000 .000$ \\
\hline 2 & |ٔ & 1 bagian x Rp 2.000 .000 & $\mathrm{Rp} \quad 2.000 .000$ \\
\hline 3 & أَبٌْ & 2 bagian $x$ Rp 2.000 .000 & $\mathrm{Rp} \quad 4.000 .000$ \\
\hline & & Jumlah & $\mathrm{Rp} 12.000 .000$ \\
\hline
\end{tabular}

2) Seorang laki-laki meninggal dunia, ahli waris : istri, ibu, dan bapak. Penyelesaiannya adalah sebagai berikut:

\begin{tabular}{|c|c|c|c|c|}
\hline \multicolumn{2}{|c|}{ Ahli waris } & \multicolumn{3}{|c|}{$\mathrm{AM}: 12$} \\
\hline 1 & زَوْجَةٌٌٌ & $1 / 4$ & 3 & 3 bagian \\
\hline 2 & أُعْمُ & $1 / 3$ sisa & & 3 bagian \\
\hline 3 & أَبٌْ & Sisa & & 6 bagian \\
\hline
\end{tabular}

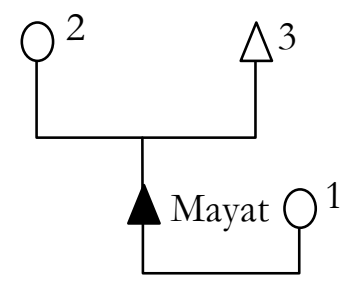

\section{Penjelasan :}

1. Bilangan 12 menjadi Asal Masalah. Perbandingan mubâyanah

2. Istri mendapat 3 bagian dan sisanya 9 bagian, diberikan pada ibu 3 bagian $(1 / 3$ sisa $)$ dan bapak 6 bagian $(2 / 3$ sisa $)$.

3. Penyelesaian di atas bagian ibu setengah dari bagian bapak. 
HP Rp 24.000.000, maka : $\frac{H P . R p 24.000 .000}{A M: 12}=R p 2.000 .000$

\begin{tabular}{|c|c|c|c|}
\hline \multicolumn{2}{|c|}{ Ahli waris } & \multicolumn{2}{|c|}{ Bagian yang diterima } \\
\hline 1 & زَوْْجَةٌ & $3 \times \mathrm{Rp} 2.000 .000$ & $\mathrm{Rp} \quad 6.000 .000$ \\
\hline 2 & أُعْم & $3 \times \operatorname{Rp} 2.000 .000$ & Rp $\quad 6.000 .000$ \\
\hline 3 & أَبٍْ & $6 \times \operatorname{Rp} 2.000 .000$ & Rp 12.000 .000 \\
\hline \multicolumn{3}{|c|}{ Jumlah } & Rp 24.000 .000 \\
\hline
\end{tabular}

\section{Dasar Bagian Tsuluts Al-Bâq}

Ibu mendapat bagian 1/3 sisa berdasarkan beberapa dalil :

Dalam ilmu farâ'idh dikenal aturan ahli waris yang sama dengan jenis yang berbeda bagian perempuan setengah dari bagian laki-laki. Pada kasus ini ibu harus memperoleh bagian $1 / 3$ sisa, yaitu $1 / 3$ nya setelah diambil bagian suami atau istri.

Bapak dan ibu, anak laki-laki dan perempuan, mempunyai kesamaan. Jika anak laki-laki bersama dengan suami menerima bagian sisa setelah diambil bagian suami dan dibagi tiga, satu bagian untuk anak perempuan, dua bagian untuk anak laki-laki, maka aturan tersebut juga berlaku untuk bapak dan ibu, jika ada suami atau istri.

Apabila ada bapak dan ibu, menurut nash Al-Qur'an bagian yang diterima ibu $1 / 3$ dan bapak sisa (2/3) bagian ibu setengah dari bagian bapak. Demikian juga apabila hanya ada bapak dan ibu bersamaan salah satu suami istri.

Ibnu Qayyim berkata, "Shahabat 'Umar bin Khaththâb dan Zaid bin Tsâbit r.a". Mengqiyaskan adanya suami dengan tanpa adanya suami. Qiyas tersebut merupakan qiyas yang baik sebab kaidah yang dipakai dalam ilmu farâ'idh, "Jika ada ahli waris tingkatannya sama jenis berbeda bagian laki-laki dua kali lebih besar". Seperti : anak dan cucu, saudara sekandung dan seayah.

Keputusan shahabat Umar bin Khaththâb ini, sejalan dengan pendapat mayoritas sahabat antara lain : Zaid bin Tsâbit, Abdullah bin Mas'ûd, dan 'Utsman bin 'Affân r.a. serta diikuti oleh mayoritas fuqahâ' madzhab empat. ${ }^{3}$

\footnotetext{
${ }^{3}$ Shâlih bin Fauzân bin 'Abdullah al-Fauzâni, at-Tahqiqah al-Mardiyyah, 1400 H, 88. 


\section{Istilah Tsulus Al-Bâq}

Penggunaan istilah tsulus al-bâq (1/3 sisa) tetapi kenyataannya $1 / 6$ dalam kasus pertama, dan $1 / 4$ dalam kasus kedua, hanya menyesuaikan dan berbuat sopan santun dengan Al-Qur'an.

Dalam surat An-Nisa': 11,

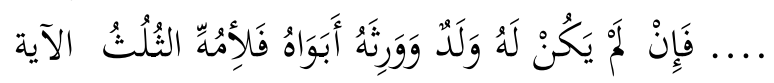

“.....jika orang yang meninggal tidak mempunyai anak dan ia diwarisi oleh ibu-bapaknya (saja), Maka ibunya mendapat sepertiga (dan bapaknya sisanya, yaitu $2 / 3$ ).....

Dalam $A r$-Rababiyyah disebutkan ${ }^{5}$

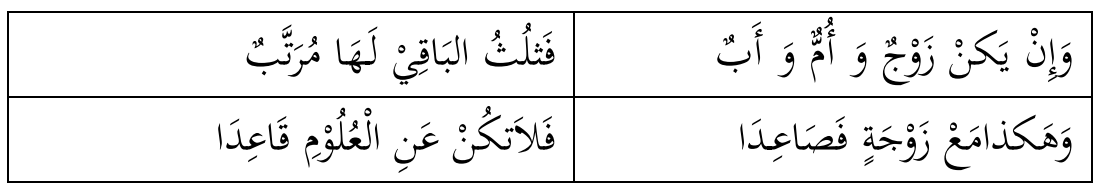

Jika dalam pembagian harta peninggalan ada suami, ibu dan bapak, maka bagian ibu sepertiga sisa. Demikian juga apabila bersama istri, maka tidak ada kaidah yang dapat dibenarkan.

Seandainya ibu mendapat bagian $1 / 3$ dari harta peninggalan, maka yang terjadi bagian ibu dua kali lebih besar dari bagian bapak dalam kasus pertama dan bagian ibu hampir sama besarnya dengan bagian bapak dalam kasus kedua.

Contoh : Kasus Pertama

\begin{tabular}{|c|c|c|c|}
\hline \multicolumn{2}{|c|}{ Ahli waris } & \multicolumn{2}{|c|}{$A M: 6$} \\
\hline 1 & زَوْجْج & $1 / 2$ & 3 \\
\hline 2 & 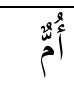 & $1 / 3$ & 2 \\
\hline 3 & أَبُجُ & Sisa & 1 \\
\hline
\end{tabular}

Contoh : Kasus kedua

${ }^{5}$ Musthafa, ar-Rạbabiyyah Ilmu Farâidh, (Damsik : Dâr al-Qalam, 2004), 57 


\begin{tabular}{|c|c|c|c|}
\hline \multicolumn{2}{|c|}{ Ahli waris } & \multicolumn{2}{|c|}{$\mathbf{A M}: 12$} \\
\hline 1 & زَوْجَةُّ & $1 / 4$ & 3 \\
\hline 2 & |⿱乛龰⿱⺈⿵⺆⿻ & $1 / 3$ & 4 \\
\hline 3 & أَبَِّ & Sisa & 5 \\
\hline
\end{tabular}

Dengan perhitungan ini ibu mendapat 2 (dua) bagian sedangkan bapak 1(satu) bagian. Berarti bagian ibu dua kali lebih besar dari bagian bapak dalam kasus pertama. Ibu mendapat 4 bagian sedangkan bapak mendapat 5(lima) bagian, berarti bagian ibu hampir sama dengan bagian bapak dalam kasus kedua.

Penyelesaian tersebut tidak mengacu pada bagian bapak dua kali lebih besar dibandingkan bagian ibu. Penyelesaian ini juga bertentangan dengan apa yang dijelaskan oleh Al-Qur'an surat An-Nisâ' : ayat, 11. Dalam surat $A n-N i s a$ : ayat 11,

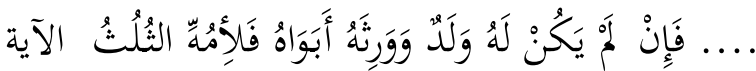

“.....jika orang yang meninggal tidak mempunyai anak dan ia diwarisi oleh ibu-bapaknya (saja), Maka ibunya mendapat sepertiga (dan bapaknya sisanya, yaitu 2/3).....

Ayat tersebut menetapkan asas bagi orang tua (ibu dan bapak) jika mayat tidak meninggalkan anak atau cucu(walad), ibu mendapat bagian $1 / 3$ sedangkan sisanya $2 / 3$ diberikan kepada bapak.

Ayat tersebut di atas juga menetapkan bangunan asas bagi orang tua, yaitu; ibu dan bapak, jika mayat tidak meninggalkan anak atau cucu (walad). Ibu mendapatkan bagian $1 / 3$ itu sama dengan satu bagian sebab ibu masuk katagori perempuan ('untsa), sedangkan sisanya yaitu $2 / 3$ sama dengan mendapatkan dua bagian sebab bapak masuk katagori ahli waris laki-laki (dzakar), oleh sebab itu kasus Ghorrawain tersebut menetapkan asas "Jika ada ahli waris yang sama namun jenisnya beda, maka perempuan mendapatkan satu bagian sedangkan laki-laki mendapatkan dua bagian". Kasus tersebut berlaku pada ahli waris sebagai berikut:

\begin{tabular}{|c|c|c|}
\hline \multicolumn{2}{|c|}{ Ahli Waris } & Asas yang ditetapkan \\
\hline 1 & Anak (Pr \& Lk) & Pr. Satu bagian Lk dua bagian \\
\hline
\end{tabular}




\begin{tabular}{|c|l|l|}
\hline 2 & Cucu (Pr \& Lk) & Pr. Satu bagian Lk dua bagian \\
\hline 3 & Sdr sekandung (Pr\&Lk) & Pr. Satu bagian Lk dua bagian \\
\hline 4 & Sdr sebapak (Pr \& Lk) & Pr. Satu bagian Lk dua bagian \\
\hline 5 & Orang tua (Ibu \& bapak) & Ibu satu bagian bapak dua bagian \\
\hline
\end{tabular}

\section{Penutup}

Dari penjelasan diatas, kasus pembagian harta waris dari seorang mayit kepada bapak adalah 1/6,1/6 plus sisa (jika ada sisa warisan), dan sisa (jika tidak ada anak atau cucu mayit). Yang perlu ditekankan adalah, ayah atau bapak disini adalah ayah kandung dari mayit. Bukan ayah tiri atau ayah angkat.

Penjelasan penjelasan disini adalah keterangan yang ada dalam kitab kitab dan juga penjabaran dari KHI khususnya pasal yang berkaitan denganwaris Islam.

\section{DAFTAR PUSTAKA}

Al-Marâghi, Ahmad Mustafa. 1974. Tafsìr Al-Marāghi, juz 4.

Al-Razi, Muhammad Fakhruddin. t.th. Tafsìr Fahr Al-Räri, Juz 6 dan 11. Beirut: Dar Al-Fikr.

Al-Suyuti, Jalaluddin. t.th. Al-Dur Al-Mantsur Fi Al-Ta wil bi Al-Ma`tsur. Beirut: Dar Al-Fikr.

Departemen Agama Republik Indonesia. 1971. Al-Qur'an dan Terjemahannya. Jakarta: Yayasan Penyelenggara / Penterjemah AlQur'an.

Quthub, Sayyid. 2001. Tafsir fi Zhiläl Al-Qur'an, Al-Mujallad Awwal dan Tsani. Beirut: Dar Al-Syuru'.

Al-'Asqalani, Ibn Hajar. t.th. Bulùgh Al-Marâm. Surabaya: Al-Hidayah.

Al-Bukhāri. t.th. Matn Al-Bukhāri, juz. 4. Singapura: Maktabah wa Mathba'ah Sulaiman.

Al-Syaukani, Muhammad bin Ali. t.th. Nail Al-Authâr, Juz 8. Beirut: Dar Al-Fikr.

Al-Fauzani, Salih bin Fauzan bin Abdullah. t.th. Al-Tahqîqah AlMardiyyah Fi Al-Mabâhits Al-Fardiyyah. Beirut: Dar Al-Fikr. 
Al-Hadrami, Sa'id bin Said Nabhan. t.th. Iddat Al-Fâridh. Surabaya: Salim Sa'id bin Said Nabhan.

Al-Lahimi, Abd Al-Karim bin Muhammad. 1986. Al-Farâ'idh. Riyadh: Matabah Al-Ma'arif.

Al-Mahâmi, Shabahi Mahmashâni. 1967. Al-Mabâdi Al-Syar'iyyah wa AlQânûniyyah. Beirut: Dar Al-'Ilm.

Al-Sahi, Syauqi Abduh. 1988. Ahkâm Al-Mawârits. Damaskus: Dar Hikmah.

Al-Shabuni, Muhammad bin Ali. 1979. Al-Mawârits Fi Al-Syariat AlIslamiyah. Beirut: Dar Al-Fikr.

Al-Zuhayli, Wahbah. 2001. Al-Farâidh wa Al-Mawârits wa Al-Washâya. Damaskus: Dar Al-Qalam.

Badawi, Syansuri. t.th. 'Ilm Al-Mawârits. Jombang: Tebuireng.

Makhluf, Muhammad Husen. 1976. Al-Mawârits Fi Al-Syarîab AlIslâmiyyah. Riyadh: Matba'ah Al-Madani.

Muhyidin, Abd Al-Hamid. 1984. Abkâm Al-Mawârits Fi Al-Syariah AlIslâmiyyah 'Ala Madhhab Al-A imah Al-Arba'ah. Beirut: Dar AlFikr.

Muslim, Musthafa. 1992. Mabâhits Fi Tlm Al-Mawârits. Jeddah: Dar AlMunarah.

Musthafa. 2004. Al-Rahabiyyah Tlm Al-Farâidh. Damaskus: Dar Al-Qalam. 